\title{
ADQUISICIÓN DE LA NACINALIDAD ESPAÑOLA Y MATRIMONIO POLIGÁMICO: ASPECTOS CRÍTICOS Y PRÁCTICOS
}

\author{
ACQUISITION OF SPANISH NACINALITY AND POLYGAMIC \\ MARRIAGE: CRITICAL AND PRACTICAL ASPECTS
}

\author{
Hani Al Rached \\ Doctor en Derecho Internacional \\ ORCID ID: 0000-0001-5547-6055
}

Recibido: 18.06.2020 / Aceptado: 03.07.2020

DOI: https://doi.org/10.20318/cdt.2020.5636

\begin{abstract}
Resumen: La nacionalidad genera un vínculo político, jurídico y social con el Estado que quiere solicitar su nacionalidad, y ello requiere que este vinculo abarque la permanencia en la tierra y la integración en las costumbres y el estilo de vida del país. Por eso, será denegada la petición de los solicitantes de la nacionalidad en los supuestos de poligamia, puesto que no cumplen el requisito de "suficiente grado de integración en la sociedad española", exigido en el art.22.4.CC. El presente trabajo trata de estudiar la eficacia del matrimonio poligámico como motivo de la denegación de la nacionalidad, tal como se pronuncia la sentencia de la Audiencia Nacional de Madrid de 4 de febrero 2019.
\end{abstract}

Palabras clave: matrimonio polígamo, denegación de nacionalidad, integración en la sociedad.

Abstract: Nationality generates a political, legal and social link with the State that wants to apply for its nationality, and this requires that this link encompasses permanence in the land and integration into the customs and lifestyle of the country. Therefore, the request of the applicants for nationality in cases of polygamy will be denied, since they do not meet the requirement of "sufficient degree of integration into Spanish society", required in art.22.4.CC. This paper tries to study the effectiveness of polygamous marriage as a reason for the denial of nationality, as pronounced by the ruling of the National Court of Madrid on February 4, 2019.

Keywords: polygamous marriage, denial of nationality, integration into society.

Sumario: I. Introducción. II. La poligamia en el Derecho musulmán, concepto y características. III. El reconocimiento de los tribunales españoles de los efectos del matrimonio poligámico y el orden público internacional atenuado. 1. El matrimonio poligámico contrasta con los principios del orden público. 2. El reconocimiento limitado de los efectos del matrimonio poligámico: una excepción del orden público internacional atenuado. IV. La eficacia del matrimonio poligámico en la denegación de la adquisición de la nacionalidad española. 1. Requisitos de la concesión de la nacionalidad en el Derecho español. 2. Análisis de la SAN de 4 de febrero de 2019: Denegación de la nacionalidad por insuficiente grado de integración en la sociedad por motivo de la poligamia. A) Los antecedentes de hecho de SAN de 4 de febrero de 2019. B) Resolución de la DGRN y las alegaciones del recurrente. C) Fundamentos de la SAN de Madrid de 4 de febrero de 2019. a) Insuficiente grado de integración en la sociedad española. b) La nacionalidad tiene carácter político y es algo más que la autorización de residencia y trabajo. c) Los informes del Fiscal y la Juez, Encargada del Registro Civil, no tienen efecto vinculante. d) Los requisitos de la concesión de la nacionalidad por residencia han de cumplirse y acreditase en el momento de la presentación de la solicitud. V. Consideraciones finales. 


\section{Introducción}

El matrimonio poligámico es rechazado y penalizado en los Códigos occidentales, puesto que «contrasta con los principios y valores de los ordenamientos occidentales» ${ }^{1}$, en particular, con el principio de igualdad entre el hombre y la mujer. También los tribunales europeos aunque reconocen algunos de los efectos del matrimonio poligámico, como por ejemplo, las pensiones de viudedad y orfandad, lo consideran contrario al orden público. El presente trabajo tiene como objeto estudiar la posición de los tribunales españoles respecto a los efectos constitutivos o nucleares del matrimonio poligámico, en concreto, la eficacia de la poligamia a la denegación de la solicitud de la nacionalidad, tal como se pronuncia la sentencia de la Audiencia Nacional de Madrid de 4 de febrero 2019. Para aclarar el tema, el estudio ha utilizado el método analítico en cuanto a la sentencia objeto de estudio, también ha empleado el método jurídico comparado, entre la Audiencia Nacional de Madrid de 2019 con la posición de otras sentencias pronunciadas por los tribunales españoles. Por último, el trabajo intenta definir los criterios que la jurisprudencia española establece en cuanto a las peticiones de la nacionalidad por residencia a los sujetos que están ligados por un matrimonio poligámico.

En la primera parte de este trabajo se explican el concepto, las características y los fundamentos de la poligamia en el Derecho musulmán, ya que el conocimiento profundo de esta institución podría facilitar y proporcionar las soluciones adecuadas para aquellos conflictos que el matrimonio poligámico suscita ante los tribunales occidentales.

\section{La poligamia en el Derecho musulmán, concepto y características}

1. Es verdad que el Derecho musulmán permite al varón casarse con más de una esposa, no obstante, esta legalización no es absoluta ni tampoco se puede practicar en cualquier circunstancia y situación. Según la perspectiva musulmana la poligamia es una medida excepcional ${ }^{2}$, que pretende resolver situaciones difíciles, como ocurre en casos de esterilidad y enfermedad de la esposa ${ }^{3}$. De acuerdo con los juristas musulmanes, si la primera esposa padece de una enfermedad crónica y por lo tanto no puede asumir sus responsabilidades matrimoniales, o bien en caso de que sufra problemas de infertilidad o tenga un impedimento congénito o patológico y no haya solución médica4; en todas las situaciones citadas el esposo puede casarse con otra mujer. Ya que, en las mismas situaciones citadas arriba, el divorcio es un derecho absoluto de la mujer si no quiere continuar la vida con su marido enfermo o impotente 5 . En este sentido, la Mudawana Marroquí de Familia establece que la esposa puede pedir la disolución del matrimonio por uno de los siguientes motivos, entre sí, "por la existencia de algún defecto y/o enfermedad de su marido que hace imposible la vida íntima entre ellos" (art.97.5).

2. Casi todas las leyes de familia en el mundo árabe conceden este derecho a la esposa, como ocurre en el Código sirio (art.105), el Derecho de familia argelino (art.53) y por último el artículo 112 del Código de Estatuto Personal de Emiratos Árabes Unidos. En resumen, el Derecho musulmán permite al varón celebrar otro segundo matrimonio si uno de los cónyuges está enfermo o estéril y el otro quiere una solución inmediata; mientras que, la mujer tiene derecho a solicitar el divorcio en caso de enfermedad, infertilidad o la impotencia de su esposo.

${ }^{1} \mathrm{M}^{\mathrm{a}}$. L. LabACa Zabala., "El matrimonio polígamo islámico y su repercusión en el Derecho español", Revista jurídica de Castilla y León, ${ }^{\circ} 18$, mayo 2009, p.267.

2 Elham ShaheEn., «Las opiniones de los sabios musulmanes respecto a la poligamia». Disponible en el periódico electrónico Alwakei, <http://alwakei.com/news/14058/index.html>. [Fecha de consulta: 04/08/2019].

${ }^{3}$ Wahba Al ZuhaYli., El Derecho musulmán y sus evidencias, Capítulo: el Estatuto Personal, 2ºd, Dar Al-Fiker, Damasco, 1985, p.170.

${ }^{4}$ Wahba Al ZuhaYli., El Derecho musulmán y sus evidencias, Capítulo: el Estatuto Personal, op.cit, pp.169- 170; MuHAMmad Madany., Una Visión Nueva sobre el tema de la Poligamia, Al-Risala, Egipto, 1958, p.20; Munammad Abu Zahra., Clases en la conclusión del Matrimonio y sus efectos, $2^{\circ}$ Ed, Dar al-Fiker Al-Arabi, Cairo, 1971, p.136.

${ }^{5}$ Wahba Al ZuhaYli., El Derecho musulmán y sus evidencias, Capítulo: el Estatuto Personal, op.cit, pp.515-516. 
3. A la luz de lo mencionado se puede decir que el fundamento que legaliza la poligamia en el Derecho musulmán está vinculado con las finalidades del casamiento musulmán, esto es, para satisfacer las necesidades sexuales y la procreación legítima ${ }^{6}$. La otra opción en este caso, esto es el divorcio, no es deseada ni permitida sin motivos razonables ${ }^{7}$, sino que es considerada como algo abominable ${ }^{8}$. Por eso, en el caso de enfermedad de la esposa el marido tiene responsabilidad moral y religiosa que le obliga a quedarse con su esposa y no divorciarse, salvo si ella misma solicita el divorcio. En este caso ella puede casarse con otro varón. En síntesis, la poligamia en la legislación musulmana es una medida excepcional, sólo se puede recurrir a ella en casos extraordinarios para mantener la familia unida y por lo tanto evitar recurrir al divorcio.

4. La poligamia no está restringida sólo por las circunstancias y situaciones citadas, sino que también se somete a varias condiciones necesarias. Según los juristas musulmanes, para contraer otro segundo matrimonio es necesario que cumplan dos requisitos: el trato igualitario a las esposas, es decir, ambas esposas deban recibir el mismo estatus y los mismos derechos sobre su esposo, como en el trato bondadoso, la vivienda, los regalos, la cohabitación nocturna y los aspectos materiales y gastos; y el segundo requisito es la estabilidad económica del esposo9. El matrimonio en el Derecho musulmán ante todo es una responsabilidad y requiere capacidad material, por eso, los varones que no pueden asumir esa responsabilidad o bien no tienen este tipo de capacidad no pueden casarse con otra esposa. Conforme a la Mudawana marroquí (art.42) y también la ley de familia argelino (art.8), el varón que quiera casarse con otra esposa debe acreditar su capacidad económica, además, debe presentar una solicitud de autorización ante el tribunal de familia, en la cual explica los motivos excepcionales para contraer otro casamiento ${ }^{10}$.

5. Respecto a la condición del trato igualitario entre las esposas, la Mudawana advierte que la poligamia será prohibida si el juez teme que con ella podría producir un trato injusto entre ambas esposas, también en caso de existencia de una cláusula en el contrato matrimonial establecida por la primera esposa de que su marido no puede casarse con otra (art.40) ${ }^{11}$. Ahora bien, después de aclarar las circunstancias y los requisitos que deban existir para que la poligamia pudiera ser permitida. En las siguientes líneas se aborda los motivos detrás de legalizar el matrimonio polígamo en el Derecho musulmán.

6. Entre los 6236 versículos del Corán, sólo se encuentra un texto que autoriza la poligamia: «Y si teméis no ser justos con los huérfanos, casaos entonces, de entre las mujeres que sean buenas para vosotros, con dos, tres o cuatro. Pero si teméis no ser equitativos, entonces con una sólo» ${ }^{12}$. Diversos

${ }^{6}$ La vida conyugal en el Derecho musulmán de familia no se limita meramente a satisfacer el placer sexual, sino que responde a otras necesidades del ser humano, ya sean psicológicas como sociales. Junto a las finalidades mencionadas, el matrimonio musulmán tiene como objetivo principal es establecer una nueva familia entre un marido y una mujer, disfrutando ambos de su ternura recíproca. Esposito JoHn señala que el casamiento musulmán está orientado para «la salvaguarda de la castidad y esencial para el crecimiento y la estabilidad de la familia, la unidad básica de la sociedad». John. Esposito., Islam, pasado y presente de las comunidades musulmanas, editorial Paidós, Barcelona, 2006, p.118.

${ }^{7}$ Muhammad Abu Zahra., Clases en la conclusión del Matrimonio y sus efectos, op.cit, p.136.

${ }^{8}$ Wahba Al Zuhayli., El Derecho musulmán y sus evidencias, op.cit, p.358; Ahmad FaEz., La familia en el Corán, $6^{\circ}$ Ed, Editorial Al-Risala, Beirut, 1992, pp.368 a 375.

9 Wahba Al ZuhaYli., El Derecho islámico y sus evidencias, op.cit, p.168; MuHAmmad ABU ZAHRA., Clases en la conclusión del Matrimonio y sus efectos, op.cit, p.134; Muhammad Mustafa Shalabi., Las disposiciones de la familia en el Islam, $4^{\circ} \mathrm{Ed}$, Al-Dar Al-Jamyiah, Beirut, 1983, p.254.

${ }^{10}$ En virtud del artículo 42 de la Mudawana: "Si no se ha pactado en el contrato de matrimonio la prohibición de la poligamia, el solicitante tendrá que pedir una autorización al Tribunal. La solicitud tendrá que exponer los motivos objetivos y excepcionales que la justifican y tendrá que ir acompañada de una declaración sobre la situación económica del solicitante". La nueva Mudawana marroquí: entre tradición y modernidad, traducción comentada del Código de familia, Junta de Andalucía, Consejería de empleo, 2004.

${ }^{11}$ En conformidad con el artículo 40 de la Mudawana: "se prohíbe la poligamia cuando puede tener lugar una injusticia entre las esposas. Está igualmente prohibida cuando la esposa haya establecido una cláusula en virtud de la cual el esposo se compromete a no tomar a otra esposa".

${ }^{12}$ El Corán, capítulo de las Mujeres, versículo 3. El Corán, Traducción y Comentario por abdel gHANI MELARA NAVIO. Disponible en: <http://noblecoran.com/index.php/coran-traducido/traduccion-de-abdel-ghani-melara $>$. [Fecha de consulta: 12/09/2019]. 
juristas musulmanes y occidentales confirman que la poligamia señalada en el texto anterior conlleva un sentido social y moral, esto es, para brindar protección a la mujer viuda y divorciada y sus hijos ${ }^{13}$. En este sentido, Catalá Santiago señala que el Islam «establece la monogamia, pero sin prohibir la poligamia, a la que da un sentido social y de protección de la mujer y de los niños de está ${ }^{14}$. Por su parte, Candela Jadicha destaca que «el Islam ha permitido la poligamia como una solución a los males sociales y ha permitido un cierto grado de libertad a la naturaleza humana, pero sólo dentro del marco estrictamente definido de la ley» ${ }^{15}$. El discurso coránico, en el mismo versículo anterior, ordena a los musulmanes desposar con sólo una mujer para que eviten cometer alguna injusticia entre sus esposas: «...pero si teméis no ser equitativos, entonces con una sólo» ${ }^{16}$.

7. Entre las opiniones que apoyan la tendencia anterior, se destaca la interpretación dada por el jurista Muhammad Madany (1907-1968 d.C), uno de los sabios del Centro Religioso de Al-Azhar en Egipto. De acuerdo con Muhammad Madany «la razón principal detrás de la legalización de la poligamia en el versículo anterior es proteger y mantener a las viudas y los huérfanos sufridos en las épocas de las guerras $\rangle^{17}$. Esto es, en los primeros años de la aparición del Islam la comunidad musulmana era pequeña, y durante la cual sucedieron muchas guerras entre los musulmanes y las tribus árabes. La comunidad musulmana ha perdido muchas vidas y murieron muchos hombres dejando viudas y huérfanos sin sostén de la familia ${ }^{18}$. El jurista Muhammad Madany aclara que el texto coránico anterior no ordena a todos los varones musulmanes que se casan con dos mujeres o más, sino que recomienda a los tutores de huérfanos que se casen con sus madres viudas, o bien con las huérfanas mismas para que puedan cuidarlas y mantenerlas de forma correcta y completa ${ }^{19}$. En otras palabras, el cuidado ofrecido por los varones a las huérfanas y viudas, en condición de tutor, se convierte una responsabilidad conyugal que no puede ceder en cualquier caso.

8. Por tanto, la poligamia en este contexto viene como una de las medidas adoptadas por la legislación musulmana para cubrir las necesidades económicas de las viudas y sus hijos huérfanos en aquella época. Ya que, como es sabido, el varón en el Derecho musulmán es el único responsable de cubrir las necesidades económicas de toda la familia ${ }^{20}$. Los juristas occidentales, como destacan Acuña Sara y Domínguez Rocío, también opinan que las razones detrás de permitir el matrimonio polígamo en el Derecho musulmán se arraigan en «cuidar y atender materialmente a los niños en caso de orfandad, concretamente a los huérfanos de hermanos o amigos, y la reforzada garantía de tutela que dogmáticamente se impone respecto de una viuda- de hermano o amigo íntimo- que la conforman en una cuasi obligación de vincularse con ella materialmente ${ }^{21}$. En la misma línea, Mandirola Pablo señala que el Profeta Muhammad «pretendía evitar la desprotección de la mujer y los hijos, otorgándose una serie de derechos inalienables $\rangle^{22}$. En síntesis, se puede concluir que la poligamia en la legislación musulmana representa una medida excepcional, tiene sus motivos y garantías, mientras que otros textos coránicos enfatizan al matrimonio monógamo.

${ }^{13}$ P. M. BRIEUX, Introducción al Derecho islámico, edición 1º, Marcial Pons, Madrid, 1998, p.107; C. R. SANTIAGO., (Coord.), Evolución del Derecho de familia en occidente, Cuenca: Ediciones de la universidad de Castilla La mancha, 2006, p.274.; J., Candela Castillo, «La poligamia en el Derecho islámico». Disponible en: $<$ http://www.webislam.com/articulos/18438-la_poligamia_en_el_derecho_islamico.html $>$, [Fecha de consulta: 18/06/2019].

${ }^{14}$ C. R. Santiago., (Coord.), Evolución del Derecho de familia en occidente, op.cit, p.274.

15 J. Candela Castillo., La poligamia en el Derecho islámico, [Fecha de consulta: 18/06/2019].

${ }^{16}$ El Corán, capítulo de las Mujeres, versículo 3. El Corán, Traducción y Comentario por A. G. MELARA NAvio. Disponible en: $<$ http://noblecoran.com/index.php/coran-traducido/traduccion-de-abdel-ghani-melara $>$. [Fecha de consulta: 12/09/2019].

${ }_{17}$ Muhammad madany., Una Visión Nueva sobre la Poligamia, op.cit, p.27.

18 Ibid, p.27.

${ }^{19}$ Muhammad Madany., Una Visión Nueva sobre la Poligamia, op.cit, p.18.

${ }^{20}$ [Las madres deberán amamantar a sus hijos durante dos años completos, si desea completar la lactancia. Sustentarlas y vestirlas es responsabilidad del progenitor]. El Corán, capítulo de la Vaca, versículo 233. Traducción y Comentario por A. G. MELARA NAVIO.

${ }^{21}$ S. AcuÑa/R.domínguez/P. LoRenzo/A. Motílla (Coord.), El matrimonio islámico y su eficacia en el Derecho español, El matrimonio islámico y su eficacia en el Derecho español, Universidad de Córdoba, Córdoba, 2003, p.37.

${ }^{22}$ P.M. BRIEUX., Introducción al Derecho islámico, op.cit, p.107. 
A continuación, se estudia el reconocimiento restringido de los ordenamientos occidentales de los efectos del matrimonio poligámico en base del orden público internacional atenuado.

\section{El reconocimiento de los efectos del matrimonio poligámico y el orden público internacional atenuado}

Abordar el conflicto que suscita el reconocimiento de los efectos generados del matrimonio poligámico, ya que éste puede resultar obstaculizado con los principios del orden público internacional.

\section{El matrimonio poligámico contrasta con los principios del orden público}

9. No cabe duda de que la poligamia representa la cuestión más polémica y criticada en el Derecho de familia musulmán. Diversos son los aspectos en los que el casamiento poligámico contrasta con la institución matrimonial en occidente. Por un lado, el matrimonio poligámico entra en conflicto con el carácter monogámico de la institución matrimonial de los Estados europeos, pues la monogamia representa uno de los elementos esenciales del casamiento ${ }^{23}$. Por otro lado, la poligamia vulnera los principios y valores de los ordenamientos occidentales, esencialmente, el principio constitucional de igualdad entre el hombre y la mujer ${ }^{24}$, tal como dispone el artículo 23 de la Carta de los Derechos Fundamentales de la Unión Europea y también la Constitución española en el art.14 en relación con el art.32.1 y el art.10.1.

10. Actualmente, los ordenamientos occidentales no permiten celebrar ni inscribir los matrimonios poligámicos en el Registro civil ${ }^{25}$. En el ordenamiento español el matrimonio monogámico es la única forma reconocida legalmente, los que están ligados con vínculo matrimonial no pueden contraer matrimonio (art.46.2.Cc) ${ }^{26}$. En este sentido, Carrascosa González y Valverde Martínez destacan que «el Derecho de Familia español arranca, en efecto, del principio básico de la monogamia matrimonial, de modo que la poligamia atenta contra la dignidad constitucional de la mujer» ${ }^{27}$.

11. Respecto a la inscripción del casamiento polígamo, Juaréz Pérez afirma que el orden público internacional «impide, hoy por hoy, que accedan al Registro Civil español los matrimonios poligámicos válidamente celebrados en el extranjero ${ }^{28}$. El casamiento poligámico, incluso, es nulo y no produce efecto alguno ante las autoridades judiciales ${ }^{29}$, tal como se refiere el apartado 2 del 73 del Código civil español. Asimismo, las legislaciones occidentales penalizan este tipo de casamiento con la pena de prisión, tal como señala el art.217 del Código penal español ${ }^{30}$.

${ }^{23}$ P. JuÁRez Pérez., "Jurisprudencia Española y poligamia islámica: ¿Un matrimonio forzoso? ", Revista electrónica de estudios internacionales (REEI), nº23, (2012), p.9.

${ }^{24}$ M. J. Valverde Martínez; J. Carrascosa González., "Poligamia en Marruecos y pensión de viudedad en España, El Tribunal Supremo y el orden público internacional atenuado", Cuadernos de Derecho Transnacional, Vol.10, n², 2018, p.720.

${ }^{25}$ A.L. Calvo Caravaca/ J. Carrascosa González., Derecho Internacional Privado, Vol.1, nº17, edición Comares, Granada, 2017, p.102 y p.105; M. V. Gómez-Urrutia., "Matrimonio poligámico, Orden público y Extranjería", Revista Actualidad Laboral (AL), n³3, 2003, p.5. Véase RDGRN de 4 de junio de 2011 (RJ. 2002/5494) y 11 de mayo 1994 (RJ. 1994/5022).

${ }^{26}$ C. M. De aguerre aldaz., (coord.); P. P. Contreras; M. Á. Pérez Álvarez., Curso de Derecho civil (IV) Derecho de familia, Colex, Madrid, 2007, p.113.

${ }^{27}$ M. J. Valverde Martínez; J. Carrascosa González., "Poligamia en Marruecos y pensión de viudedad en España, El Tribunal Supremo y el orden público internacional atenuado", op.cit, p.720. En este sentido viene RDGRN de 8 de marzo de 1995 (RJ. 1995/2601)

${ }^{28}$ P. JuARéz Pérez., "La Consolidación de una lúcida Doctrina Judicial sobre poligamia y pensión de viudedad: La STSJ de Andalucía de 24 de Mayo de 2018", Cuadernos de Derecho Transnacional, vol.11, nº1, 2019, p.804.

${ }^{29}$ S.acuña/ R. Domínguez/ P. Lorenzo; A. Motílla, (Coord.), El matrimonio islámico y su eficacia en el Derecho español, op.cit, p.157.

${ }^{30}$ M. J. Valverde Martínez; J. Carrascosa González., Poligamia en Marruecos y pensión de viudedad en España, op.cit, p.720. 
12. La conservación del principio de unidad del vinculo matrimonial y la igualdad entre el hombre la mujer, representan un obstáculo ante la admisión de los efectos de la poligamia como institución jurídica repugna estos principios. El motivo como aclara Labaca Zabala es que «el impedimento de ligamen y la prohibición de la poligamia, se configura en nuestro sistema matrimonial, como cuestiones de orden público directamente derivados del derecho constitucional a la dignidad personal» ${ }^{31}$. La sentencia de la Audiencia Nacional, eje de este estudio, enfatiza de los principios citados y que considera que el orden público constituye «el conjunto de aquellos valores fundamentales e irrenunciables sobre los que se apoya nuestro entero ordenamiento jurídico, resulta incuestionable la incompatibilidad con el mismo de la poligamia; y ello sencillamente porque la poligamia presupone la desigualdad entre mujeres y hombres, así como la sumisión de aquéllas a éstos». Por su parte, la sentencia de la Audiencia Provincial de Granada de 2003 declara que "el delito de bigamia supone un ataque frontal a la institución familiar, en cuanto que la misma tiene su fundamento en el matrimonio y éste responde en nuestro país, al igual que en la mayoría de los países civilizados, a la concepción monógama, lo que lleva al legislador a criminalizar y sancionar la conducta del que, contrajere segundo o ulterior matrimonio sin hallarse legítimamente disuelto el anterior" ${ }^{\prime \prime 2}$.

A pesar de la fuerte condena de la poligamia, si bien, algunas legislaciones occidentales tienden a reconocer algunos de los efectos del casamiento poligámico ${ }^{33}$, en base de la teoría de "orden público atenuado".

\section{El reconocimiento limitado de los efectos del matrimonio poligámico: una excepción del orden público internacional atenuado}

13. En principio, en conformidad con las normas del Derecho internacional privado la ley extranjera que vulnera el orden público será rechazada y no hay cabida para su aplicación en ningún caso. En virtud del Código Civil español "en ningún caso tenderá aplicación la ley extranjera cuando resulte contraria al orden público" (art.12.3-CC). Los tribunales españoles también deciden que la institución de la poligamia es incompatible con el sistema jurídico y repugna al orden público. El Tribunal Supremo considera que "la poligamia no es simplemente algo contrario a la legislación española, sino algo que repugna al orden público, que constituye siempre un límite infranqueable a la eficacia del derecho extranjero"34. Carrascosa González y Valverde Martínez explican que «aplicar en su integridad en España la Ley marroquí que admite el matrimonio poligámico produciría un daño a los principios jurídicos básicos sobre los que se asienta la convivencia y cohesión de la sociedad española» ${ }^{35}$.

14. No obstante, la aplicación estricta del orden internacional y el rechazo total de los efectos del casamiento poligámico no logra la seguridad jurídica, ya que deja a la viuda del polígamo y sus hijos sin cobertura económica y protección jurídica. Entonces, para evitar la desprotección económica y jurídica a la familia del polígamo ha surgido dentro de la doctrina y la jurisprudencia una tendencia hacia una interpretación más flexible y razonable del orden público. De hecho, los tribunales adoptaron un nuevo concepto respecto al matrimonio poligámico, esto es, "orden público atenuado o flexible" ${ }^{36}$. En este sentido, Cervilla Garzón aclara que «los tribunales entienden que el concepto de orden público no es rígido,

${ }^{31}$ L. Ma . Labaca Zabala., El matrimonio poligámico islámico y su trascendencia en el ordenamiento jurídico español, Cartapacio de Derecho: Revista Virtual de la Facultad de Derecho, nº14, 2008, p.32.

${ }^{32}$ Sentencia de la Audiencia Provincial de Granada de 25 de marzo de 2003, F. J. $3^{\circ}$.

${ }^{33}$ L. Ma . LabACA ZABALA., "El matrimonio poligámico islámico y su trascendencia en el ordenamiento jurídico español", op.cit, p.38.

${ }^{34}$ Sentencia del Tribunal Supremo, Sala de los Contencioso-Administrativo, de 26 de febrero de 2010, $\mathrm{n}^{\circ} 5507 / 2006$, el Cuarto de los Fundamentos de Derecho.

${ }^{35}$ M. J. Valverde Martínez/J. Carrascosa GonzÁlez., Poligamia en Marruecos y pensión de viudedad en España, op.cit, p.727.

${ }^{36}$ La teoría de "orden público atenuado", como es sabido, ha surgido como consecuencia de la resolución emitida por la Corte de Casación, el 17 de abril de 1953, tras la sentencia Riviére del Tribunal de Casación. A. CAlvo CaravaCA/ J. CARRASCOSA GonZÁLEZ., Derecho Internacional Privado, op.cit, pp.628-630. 
sino que puede flexibilizarse en función de las circunstancias concurrentes en el caso concreto y cuando se producen los presupuestos anteriormente mencionados», esto es, en caso de desprotección jurídica y económica de la familia del polígamo ${ }^{37}$. Por su parte, Calvo Caravaca .A y Carrascosa González .J, opinan que «en el fondo, admitir en España ciertos efectos jurídicos de ese matrimonio poligámico, válidamente celebrado en el extranjero, no daña el orden público internacional español» ${ }^{38}$. Según los mismos autores la solución más justa y equitativa ${ }^{39}$ es «aceptar un orden público internacional "atenuado" que permite hacer valer en España algunos efectos jurídicos derivados del matrimonio poligámico» ${ }^{40}$.

15. En la misma línea, Fernández Rozas y Sánchez Lorenzo afirman que «los matrimonios poligámicos o poliándricos son, pues, contrarios al orden público español [...], aunque, tal y como ha señalado reiteradamente la DGRN, a menudo es deseable un efecto atenuado de dicha reserva, para garantice una adecuada protección jurídica y económica de la familia, reconociendo alimentos, derechos sucesorios 0 , incluso, pensiones de viudedad, a los sucesivos cónyuges ${ }^{41}$. Se puede concluir que la admisión de ciertos efectos del casamiento poligámico no produce un daño fundamental a la sociedad española y no perjudica a ningún particular, sino que al contrario contribuyen a la instauración de la justicia formal ${ }^{42}$.

16. Actualmente, algunas legislaciones occidentales reconocen de ciertos efectos de las uniones poligámicas, siempre y cuando la ley de estatuto personal de ambos contrayentes permita la poligamia, y que el segundo matrimonio haya sido concluido en un país extranjero que permite la poligamia ${ }^{43}$. «La legislación española reguladora de la Seguridad Social concede, en ciertas condiciones, una pensión de viudedad al cónyuge supérstite» ${ }^{44}$. En los últimos años se destacan varias sentencias de los tribunales españoles en los que reconocen el derecho de la pensión de viudedad a la esposa del polígamo ${ }^{45}$. Las últimas sentencias han sido del Tribunal Superior de Justicia de Andalucía, Sevilla de 24/05/2018 ${ }^{46}$, y la del Tribunal Supremo (Sala de lo Contencioso-Administrativo) de 21 de Enero 2020. En ambas sentencias el Tribunal ha decidido distribuir la pensión de viudedad por partes iguales entre las esposas que hayan estado simultáneamente casadas con el mismo causante, y el fallecido es de origen marroquí. El hecho de no reconocer ciertos efectos del matrimonio poligámico podría llevar a consecuencias negativas, es decir, dejar en total desprotección a las esposas e hijos del polígamo. En suma, es admisible el reconocimiento de ciertos efectos del matrimonio poligámico, celebrado válidamente en el extranjero,

${ }^{37} \mathrm{M}^{\mathrm{a}}$.J. Cervilla Garzón., "Identidad islámica y orden público: los efectos del matrimonio poligámico en el sistema español de seguridad social", Cuadernos de Derecho Transnacional, Vol.11, nº1, 2019, p.246.

38 A. Calvo Caravaca/ J. carrascosa González., Derecho Internacional Privado, op.cit, 102.

${ }^{39}$ M. J. Valverde Martínez; J. Carrascosa GonzÁlez., Poligamia en Marruecos y pensión de viudedad en España, op.cit, p.727.

40 A. Calvo Caravaca/ J. Carrascosa González., Derecho Internacional Privado, op.cit, p.102.

${ }^{41}$ J. C. Fernández Rozas/S. Sánchez Lorenzo, Derecho Internacional Privado, $10^{\circ}$ Ed, Thomson Reuters, Pamplona, 2018, p.452.

${ }^{42} \mathrm{M}^{\mathrm{a}}$. J. Cervilla Garzón., Identidad islámica y orden público: los efectos del matrimonio poligámico en el sistema español de seguridad social, op.cit, p.246.

${ }^{43}$ Concretamente, del ATS CA 8 enero 2018 (RJ/2018/16958), así como de la STS Núm.84/2018 de 24 enero (RJ/2018/130) y del ATS 21 MARZO 2017 (RJ/2017/73144), se desprende que, pese a no existir unanimidad de criterios, la postura mayoritaria de los Tribunales de Justicia de las CCAA se muestran a favor de aplicar la tesis de los efectos atenuados del orden público internacional. Así, aplicando dicha teoría, permiten que el matrimonio poligámico, sin ser reconocido, despliegue determinados efectos, como es el reconocimiento de la pensión de viudedad a las diferentes esposas de un varón polígamo, ya que ello no vulnera los principios fundamentales del ordenamiento español. Véase $\mathrm{M}^{\mathrm{a}}$. J. SÁNChEZ CANO., "Poligamia y Derecho Internacional Privado ante el Tribunal Supremo", en A. L Calvo Caravaca/ J. Carrascosa González, (Dir.), El Tribunal Supremo y el Derecho Internacional Privado", Vol.2., Colección Derecho y Letras, Vol.I, Murcia, 2019, pp.529-544.

${ }^{44}$ M. J. Valverde Martínez/ J. Carrascosa González., Poligamia en Marruecos y pensión de viudedad en España, op.cit, p.721.

${ }^{45}$ La primera sentencia que reconoció el derecho a la pensión de viudedad a dos esposas es la Sentencia del Juzgado de los Social (n³) de la Coruña, (núm. 2001/1493), de 13 de julio de 1998. Luego, viene la sentencia del Tribunal Superior de Justicia Galicia, (núm. 2002/899), de 2 de abril de 2002. Tribunal Superior de Justicia de Madrid, sentencia núm. 2002/3324 de 29 de julio 2002.

${ }^{46}$ Sentencia del Tribunal Superior de Justicia de Andalucía, Sevilla (Sala de lo Social, Sección 1ª) núm. 1589/2018 de 24 mayo. Véase P. JuARéz Pérez., La Consolidación de una lúcida Doctrina Judicial sobre poligamia y pensión de viudedad: La STSJ de Andalucía de 24 de Mayo de 2018. 
conforme al art.65.CC y el art. 256.RRC, aunque su estructura jurídica contravenga el orden público internacional (art.12.3.CC).

17. En cambio, las autoridades judiciales rechazaron otros efectos del matrimonio poligámico, como ocurre en varias ocasiones en la concesión de la nacionalidad ${ }^{47}$. Según Juárez Pérez, existen varias sentencias que deniegan la nacionalidad al solicitante polígamo, el argumento común entre las resoluciones judiciales es la "falta de integración en la sociedad española"48, como se destaca la sentencia de 4 de febrero de 2019 de la Audiencia Nacional de Madrid. Se puede afirmar que en casos de los polígamos que solicitan la nacionalidad española, como señala Sánchez Cano, «el orden público internacional opera en forma plena y de manera estricta $»^{49}$. Esto es, los polígamos que solicitan la nacionalidad española su petición siempre ha sido desestimada.

18. La posición oscilante de los tribunales europeos de admitir algunos efectos del casamiento poligámico y rechazar otros debe ser interpretada en la conservación de los principios y valores del orden público por un lado; y respetar los derechos establecidos en los Convenios y Acuerdos europeos de Derechos Humanos por otro lado, en este sentido, garantizar la protección económica y jurídica a la esposa y los hijos del marido polígamo ${ }^{50}$. De todo lo mencionado se puede decir que los ordenamientos occidentales reconocen algunos efectos del matrimonio poligámico en base de la teoría del orden público internacional atenuado. Los efectos del matrimonio poligámico que podrían ser admitidos ante los tribunales europeos son los efectos periféricos, como ocurre en las pensiones de la viudedad. Mientras que, los efectos constitutivos o nucleares, como en el caso de la adquisición de la nacionalidad o inscribir el matrimonio poligámico en el Registro Civil, éstos serán rechazados totalmente ${ }^{51}$.

La última y tercera parte del estudio trata la denegación de la nacionalidad en caso de los solicitantes ligados por vínculo matrimonial poligámico, tal como se pronuncia en la sentencia de la Audiencia Nacional de 4 de febrero de 2019.

\section{Eficacia del matrimonio poligámico a la denegación de la nacionalidad}

19. A partir de los años 2001 y 2002 hasta la actualidad los tribunales españoles consideran que la poligamia representa un obstáculo para la concesión de la nacionalidad española por residencia, «por no satisfacer el requisito previsto en el artículo 22.4 del Código Civil referido al "suficiente grado de

\footnotetext{
${ }^{47}$ Entre las sentencias se destaca la Sentencia del Tribunal Supremo (Sala de lo Contencioso-Administrativo, Sección 5.a) de 26 de febrero de 2010. SAN de 6 de mayo de 2010 (Sala de lo Contencioso-Administrativo, JUR $2010 \backslash 174556$ ). SSAN de 23 noviembre 2000 (JUR 2001\174948), 12 junio 2001 (JUR 294445), 11 junio 2002 (JUR 2003/58420), 27 enero 2005 (RJCA 2005\840), 8 marzo 2005 (JUR 2006\273879), 14 septiembre 2006 (JUR 2006\245537), 11 julio 2007 (JUR 2007\229136). Véase P. JuARÉz Pérez., Jurisprudencia Española y poligamia islámica: ¿Un matrimonio forzoso?, op.cit, p.27 y p.29.

${ }^{48}$ P. JuArÉz PÉrez., Jurisprudencia Española y poligamia islámica: ¿Un matrimonio forzoso?, op.cit, p.27.

${ }^{49} \mathrm{M}^{\mathrm{a}}$. J. Sánchez Cano., "Poligamia y Derecho Internacional Privado ante el Tribunal Supremo", en A. L. Calvo Caravaca/ J. Carrascosa González., (Dir.), El Tribunal Supremo y el Derecho Internacional Privado, op.cit, pp.529-544.

${ }^{50}$ Desde el punto de vista jurídico, no existe convención alguna que regula exclusivamente la condición de la mujer viuda del marido polígamo. Si bien, no se debe olvidar que las Declaraciones de las Naciones Unidas y los Convenios internacionales aluden en muchas ocasiones a los derechos de la mujer, y instan a los Estados Partes a tomar las medidas necesarias que garantizan estos derechos, entre sí, la seguridad económica. La Declaración Universal de Derechos Humanos aprobada en 1948 establece en su artículo 25 el derecho de toda persona a la propiedad, el derecho a un nivel de vida adecuado, incluida la vivienda, y a seguro en caso de pérdida de sus medios de subsistencia. En el mismo sentido, el Pacto Internacional de Derechos Económicos, Sociales y Culturales de 1966 viene a confirmar el derecho de toda persona, ya sea hombre o mujer, a un nivel de vida adecuado para sí y su familia. La Declaración Universal también confirma el derecho a toda persona a la seguridad social (art.22). De conformidad con los textos consagrados en los instrumentos de las Naciones Unidas y los Convenios y Tratados internacionales la mujer tiene diversos derechos garantizados por los Estados, sin distinguir entre una familia polígama o monógama. En otras palabras, el derecho de la mujer viuda del polígamo a una pensión justa y asegurada tiene base legal en el contexto de los Convenios y Tratados internacionales

${ }^{51}$ A. L. Calvo Caravaca/ J. Carrascosa González., Derecho Internacional Privado, op.cit, p.102 a p.105.
} 
integración" con los valores sociales y culturales de la sociedad española $»^{52}$. La Audiencia Nacional de Madrid (Sala de lo Contencioso-Administrativo, sección $8^{\mathrm{a}}$ ) en su sentencia de 4 de febrero de 2019, desestima el recurso contencioso-administrativo, interpuesto contra la Resolución del Ministerio de Justicia que deniega la nacionalidad española a un ciudadano senegalés al no haber renunciado a la poligamia en el momento de la solicitud.

Antes de analizar la sentencia es necesario explicar las condiciones exigidas por la ley española para obtener la nacionalidad, en concreto, la condición relacionada con la acreditación de un suficiente grado de integración en la sociedad, ya que esta condición es el motivo de la denegación de la nacionalidad en la sentencia objeto de estudio.

\section{Requisitos de la concesión de la nacionalidad en el Derecho español}

20. Conforme a las normas del Código civil español, tal como disponen los artículos 21.2 y 22 , para poder adquirir la nacionalidad por residencia es necesario que el solicitante reúna ciertos requisitos $^{53}$. El primero es que el interesado deba acreditar que haya residido en España de forma legal, continuada e inmediatamente anterior a la petición, un periodo de un año, dos, cinco o diez años (22.Cc). En general, los ciudadanos procedentes de países árabes y musulmanes, donde la poligamia es permitida, como por ejemplo en Marruecos y Senegal, éstos deban acreditar en el momento de la presentación de la solicitud de la nacionalidad que hayan residido en España un periodo de diez años. En virtud del apartado 1 del artículo 22: «para la concesión de la nacionalidad por residencia se requiere que ésta haya durado diez años». La segunda de las condiciones se refiere al carácter de la residencia que el interesado debe cumplir en España, esto es, una residencia legal, continuada e inmediatamente anterior a la petición ${ }^{54}$.

21. Junto a los dos requisitos mencionados, el artículo $22 . \mathrm{CC}$ añade otras dos condiciones necesarias, una buena conducta cívica y un suficiente grado de integración en la sociedad española. Conforme el apartado 4 del artículo 22.CC «el interesado deberá justificar en el expediente regulado por la legislación del Registro Civil, buena conducta cívica y suficiente grado de integración en la sociedad española». En cuanto al tercer requisito, la ausencia de antecedentes penales o policiales no considera un elemento suficiente para justificar la buena conducta cívica, sino que es necesario tener en cuenta otros datos del comportamiento del peticionario. Espinar Vicente afirma que «ciertamente, buena conducta cívica no se acredita únicamente a través de certificaciones de las que se deduzca que el sujeto no ha realizado actividades penalizadas por la legislación criminal $»^{55}$. En la misma línea, Cobas Cobiella señala que «a la hora de hacer las valoraciones del civismo de quien solicita la adquisición de la nacionalidad española por residencia deben ponderarse cualesquiera otros datos positivos o negativos que, al margen de lo penal, puedan poner de manifiesto cuál es la actitud del solicitante en la sociedad $»^{56}$. El cuarto de entre los requisitos exigidos para obtener la nacionalidad española, es que el promotor de la solicitud deba acreditar "un suficiente grado de integración en la sociedad española". Todos los requisitos han de cumplirse y acreditarse en el momento de la solicitud para poder adquirir la nacionalidad española por residencia. El cuarto de entre los requisitos exigidos para obtener la nacionalidad española constituye el motivo principal de la denegación de la nacionalidad en la sentencia. A continuación, nos centramos en este requisito explicándose su contenido y significado.

${ }^{52}$ A. M. Asín CABrera., "La práctica judicial española ante la diversidad multicultural de la relaciones familiares", Anuario de la inmigración en España, 2015, p.307.

53 J. Carrascosa GonzÁlez., "Adquisición de la nacionalidad española por residencia en España art.22", en M. PASQUAU Liaño., Jurisprudencia Civil Comentada: Código Civil, Comares editorial, Granada, Tomo I, 2000, p.454.

${ }^{54}$ El artículo 22 del Código civil, en su apartado 3, dispone que «en todos los casos, la residencia habrá de ser legal, continuada e inmediatamente anterior a la petición».

55 J. M. Espinar Vicente., Tratado Elemental de Derecho Internacional Privado, Universidad de Alcalá, Madrid, 2008, pp.182-183.

${ }^{56}$ E. Ma . Cobas Cobiella., "Una Mirada a los requisitos de la obtención de la nacionalidad española por residencia", Barataria: Revista Castellano-Manchega de ciencias sociales, Vol.17, nº17, p.238. 
22. Los preceptos jurídicos citados en el apartado 4 «no contienen una definición legal comprensiva de los parámetros de determinación del grado de integración social de los solicitantes por lo que es incierta hasta su apreciación en sede judicial $»^{57}$. En otras palabras, los términos jurídicos del apartado 4 del artículo 22.CC no determinan cuáles son los criterios necesarios para cumplir la condición de "suficiente grado de integración en la sociedad española". Ahora bien, un estudio detenido de los informes y actas emitidos por las autoridades administrativas y judiciales, respecto a las solicitudes de nacionalidad presentadas por extranjeros, nos sugiere que existen diversos criterios que deban concurrir en el solicitante de la nacionalidad para poder decir que éste último cumpla este requisito. Esto es, las autoridades administrativas y judiciales a la hora de valorar las solicitudes de nacionalidad aplican varios criterios vinculados con aspectos legales, sociales, culturales y económicos. De acuerdo con Almargo Rodríguez «existe un núcleo de datos de comportamiento "españoles" que son siempre exigibles a todo sujeto extranjero que desea adquirir la nacionalidad española por residencia» ${ }^{58}$.

23. El motivo que exige aplicar esta serie de criterios se encuentra en la gran diferencia entre los españoles y los extranjeros que pretenden adquirir la nacionalidad, en la mayoría de los casos pertenecen a otras culturas diferentes, en particular, los ciudadanos procedentes del mundo árabe o países musulmanes de África o Asia, turcos, senegaleses o marroquíes. Por otro lado, «la nacionalidad genera un vínculo político, jurídico y social con el Estado, y ello requiere que este vinculo abarque la permanencia en la tierra y la integración a la misma, a las costumbres del país, a la cultura a un estilo de vida determinado» ${ }^{59}$. En palabras de Carrascosa González, el concepto de "suficiente grado de integración en la sociedad" exige «una fuerte vinculación y arraigo» entre el solicitante y la sociedad española ${ }^{60}$.

24. A la luz de lo mencionado se puede concluir que las autoridades no se conforman sólo con los plazos establecidos para conceder la nacionalidad, es decir, "una residencia legal, continuada e inmediatamente anterior a la petición", sino que es necesario que el solicitante de la nacionalidad se integre con la sociedad, acepte sus normas y leyes y se adapte a sus costumbres y su cultura ${ }^{61}$. El manejo de la lengua representa uno de los parámetros más importantes que demuestran que el interesado está integrado en la sociedad española. La Espina Encarnación señala que «la práctica habitual en el Derecho comparado europeo es considerar el manejo del idioma como un elemento indispensable y revelador del nivel de integración social del extranjero que pretende obtener la nacionalidad del país en el que reside» ${ }^{62}$. El art.220 del Reglamento de la Ley del Registro Civil, sección $7^{\circ}$ de la nacionalidad, apartado $5^{\circ}$, exige en la solicitud de la nacionalidad si el extranjero «.....habla castellano u otra lengua española; cualquier circunstancia de adaptación a la cultura y estilo de vida españoles, como estudios, actividades benéficas o sociales, y las demás que estime conveniente». El Tribunal Supremo en dos sentencias considera que «el conocimiento del idioma español se exige en la medida que el mismo resulta necesario para entablar relaciones sociales con terceros en grado suficiente para procurar una integración efectiva en la sociedad ${ }^{63}$.

25. Junto al manejo de la lengua, el desarrollo de actividades laborales por el solicitante a lo largo de su estancia en España se considera índice significativo de la integración del interesado en la sociedad. Por último, el solicitante de la nacionalidad para cumplir el requisito de la integración social es necesario

${ }^{57}$ E. Ma. La Spina., "Más allá de (ir)refutable nexo poligamia-desintegración social en la jurisprudencia ContenciosoAdministrativa del Tribunal Supremo", Anales de la Cátedra Francisco Suárez, n48, 2014, p.226.

${ }^{58}$ N. Ma . Almargo Rodríguez., "Comentario A la sentencia de la Sala de lo Contencioso-Administrativo del Tribunal Supremo, de 19 de junio de 2008, sobre denegación de la concesión de la nacionalidad española por poligamia", Cuadernos de Derecho Transnacional, Vol.1, n², octubre, 2009, p.276.

${ }^{59}$ E. M ${ }^{\text {a }}$. CoBas Cobiella., Una Mirada a los requisitos de la obtención de la nacionalidad española por residencia, op.cit, p.236.

${ }^{60}$ J. CARrascosa GonZÁlez., Adquisición de la nacionalidad española por residencia en España art.22, op.cit, p.454.

${ }^{61}$ E. M ${ }^{\mathrm{a}}$. Сobas Cobiella., Una Mirada a los requisitos de la obtención de la nacionalidad española por residencia, op.cit, p.236.

${ }^{62}$ E. Ma . La Spina., Más allá de (ir)refutable nexo poligamia-desintegración social en la jurisprudencia ContenciosoAdministrativa del Tribunal Supremo, op.cit, p.225.

${ }^{63}$ STS de 25 de febrero de 2010, Sala de los Contencioso-Administrativo, número 5507/2006, y STS de 18 de noviembre de 2010, Rec. 4729/2007. 
que admita y respete las normas y disposiciones fundamentales del Estado previstas en su Constitución y sus leyes. Se puede decir que el requisito de "suficiente grado de integración en la sociedad española" no se limita a los elementos sociales y económicos sino también abarca el aspecto jurídico. En este sentido, la Audiencia Nacional en su sentencia de 4 de febrero de 2019, aclara que la jurisprudencia viene razonando que el requisito de "suficiente grado de integración en la sociedad" exige «la armonización del régimen de vida del solicitante con los principios y valores sociales, que en gran parte tienen reflejo constitucional, su grado de implicación en las relaciones económicas, sociales y culturales, así como su arraigo familiar, todo lo cual ha de justificarse por el interesado o desprenderse de las actuaciones reflejadas en el expediente administrativo ${ }^{64}$. De todo lo mencionado se puede concluir que el extranjero que quiere solicitar la nacionalidad ha de reunir una serie de requisitos formales legales, conforme al artículo 22.Cc. En cuanto el requisito de "suficiente grado de integración en la sociedad española", las autoridades aplican varios criterios vinculados con aspectos sociales y culturales, y otros conllevan carácter jurídico. A continuación, se analiza la sentencia de la Audiencia Nacional de 4 de febrero de 2019.

\section{Análisis de la SAN de Madrid de 4 de febrero de 2019: Denegación de la nacionalidad por insu- ficiente grado de integración en la sociedad por motivo de la poligamia}

\section{A) Los antecedentes de hecho de la SAN de 4 de febrero de 2019}

26. La Sentencia de la Audiencia Nacional de Madrid (Sala de lo Contencioso-Administrativo, Sección Octava), de 4 de febrero de 2019, fue dictada como respuesta al recurso contencioso-administrativo, núm.1099/2017, presentado por un ciudadano nacional de la República de Senegal, contra la Resolución del Ministerio de Justicia, de fecha 15 de junio de 2017, sobre denegación de la nacionalidad por residencia. En la fecha de 16 de diciembre de 2010 el ciudadano José Ramón presentó su solicitud de nacionalidad española por residencia.

27. No obstante, en la fecha de 15/07/2015, la DGRN por delegación del Ministro de Justicia, no admitió la solicitud de nacionalidad por residencia. El motivo de la denegación fue que el interesado presentó entre los documentos de la solicitud de la nacionalidad un certificado de matrimonio de la República de Senegal, en el que se consignaba que contrajo matrimonio en la ciudad de Diourbel en la fecha de 13/02/1993, declarando las dos esposas, "poligamia".

28. Contra la resolución denegatoria de la nacionalidad del Director General de los Registros y del Notariado, el interesado interpuso recurso de reposición en el 03/12/2015, aportando un nuevo certificado matrimonial, actualizado, legalizado y traducido, donde se hace constar que ha optado, junto a su esposa, por acogerse al régimen matrimonial de comunidad de bienes, realizando una declaración expresa por acogerse a la monogamia y renunciando a la poligamia. Sin embargo, la DGRN desestimó el recurso de reposición con fecha 15 de junio de 2017, confirmando la resolución denegatoria de la nacionalidad.

29. Ante la confirmación de la denegación de la nacionalidad por la DGRN, el interesado presentó recurso contencioso-administrativo ante la Audiencia Nacional. La Audiencia Nacional, en la sentencia de 4 de febrero de 2019, desestimó el recurso contencioso-administrativo interpuesto contra la Resolución del Ministro de Justicia, confirmando la resolución de la DGRN.

\section{B) Resolución de la DGRN y las alegaciones del recurrente}

30. Según la DGRN el motivo de la denegación de la solicitud de la nacionalidad es que el recurrente no cumple el requisito del "suficiente grado de integración en la sociedad española" (art.22.4.CC).

${ }^{64}$ Apartado tercero de los Fundamentos de Derecho del fallo de la SAN de Madrid de 4 de febrero de 2019. 
Conforme a la resolución del Director General de los Registros y del Notariado: «el interesado no ha justificado suficiente grado de integración en la sociedad española conforme a lo previsto en el artículo 22.4.CC, dado que se desprende del expediente que no descarta la poligamia, por cuanto en el certificado de matrimonio ya celebrado consta que el solicitante optó por el régimen de poligamia».

31. A pesar de que el recurrente demuestra suficiente asimilación del idioma y adaptación a la cultura española, tal como señala el acta de audiencia con el Juez-Encargado del Registro Civil, si bien, el recurrente practica la poligamia y esto significa que no respeta las disposiciones legales, entre ellas, el principio de unidad del vínculo matrimonial previsto en el Derecho español (art.46.2CC). Por lo tanto, el recurrente no cumple el requisito del "suficiente grado de integración en la sociedad española. La DGRN enfatiza que «la integración en cualquier sociedad exige la aceptación y seguimiento de sus principios sociales básicos, especialmente aquellos recogidos en disposiciones legales que disciplinan los presupuestos esenciales de la convivencia entre ciudadanos ${ }^{65}$.

32. La DGRN para fundamentar su resolución recurre a la jurisprudencia del Tribunal Supremo que declara claramente que la poligamia es contraria al orden público. En este sentido, la DGRN señala que «la jurisprudencia ha declarado de forma reiterada que la poligamia es contraria al orden público español, que constituye siempre un límite infranqueable a la eficacia del Derecho extranjero, por lo que resulta irrelevante que la poligamia esté admitida en el país de origen del solicitante, (SSTS de 14 de julio de 2004, 19 de junio de 2008 y 14 de julio de 2009, entre otras) $»^{66}$.

33. Por su parte, el recurrente invoca en su defensa que cumple todos los requisitos de los artículos 21 y 22.CC, todos ellos acreditados en el expediente administrativo. El interesado presentó en el expediente administrativo, como señala el apartado cuarto de los Fundamentos de Derecho de la sentencia, todos los documentos exigidos por la ley. Entre los otros documentos presentados, junto con la solicitud: certificado de nacimiento, certificado de inscripción consular en el Consulado de la República de Senegal en Canarias, pasaporte, permiso de residencia permanente, certificado de empadronamiento en el Ayuntamiento de Arona, certificado de buena conducta expedido por el Cónsul Honorario de la República de Senegal en Canarias, certificación acreditativa de carecer de antecedentes penales en su país y por último Informe de vida laboral.

34. Además, el Fiscal y la Juez, Encargada del Registro Civil, emitieron dos informes favorables a la concesión de la nacionalidad española al interesado. Por otro lado, el recurrente invoca que, tras la denegación de la nacionalidad por la DGRN, presentó escrito de ampliación y mejora del recurso de reposición presentado el 03/12/2015, adjuntado al mismo certificado de matrimonio actualizado, legalizado y traducido, donde se hace constar que ha optado, junto a su esposa, por acogerse al régimen matrimonial de comunidad de bienes, realizando una declaración expresa por acogerse a la monogamia, rechazando la poligamia. No obstante, la DGRN no ha tenido en cuenta el nuevo documento presentado en la que renuncia a la poligamia, confirmando la resolución denegatoria de la nacionalidad.

35. La Audiencia Nacional después de estudiar el recurso expuesto no ha admitido las alegaciones del recurrente en su defensa, y desestimó el recurso contencioso-administrativo por diversos motivos, tal como aparecen en los fundamentos del fallo.

\footnotetext{
${ }^{65}$ En el mismo sentido viene la Resolución de DGRN de 10 de noviembre de 2015: "Tanto la Audiencia Nacional como el Tribunal Supremo exigen una palmaria claridad respecto a los vínculos matrimoniales que lleve a entender que el solicitante se encuentra acomodado a las costumbres españolas en la estructuración de sus relaciones familiares. La integración en cualquier sociedad exige la aceptación y seguimiento de sus principios sociales básicos, especialmente aquellos recogidos en disposiciones legales que disciplinan los presupuestos esenciales de la convivencia entre ciudadanos".

${ }^{66}$ STS de 14 de julio de 2004, 19 de junio de 2008 y 14 de julio de 2009.
} 


\section{C) Fundamentos de la SAN de Madrid de 4 de febrero de 2019}

36. El motivo principal de desestimar el recurso contencioso-administrativo, interpuesto contra la Resolución denegatoria de la nacionalidad de la DGRN, es que el recurrente no cumple efectivamente el requisito del "suficiente grado de integración en la sociedad española". Si bien, la Audiencia Nacional alude a otros fundamentos importantes, sustanciales y formales, que refutan las alegaciones del recurrente.

\section{a) Insuficiente grado de integración en la sociedad española}

37. La concesión de la nacionalidad española por residencia, como señala la Audiencia Nacional en el tercero de los Fundamentos de Derecho, sujeta a dos tipos de requisitos: "unos de carácter definido, como son la formulación de la correspondiente solicitud y la residencia legal, continuada e inmediatamente anterior a la petición durante los plazos de diez, cinco, dos o un año, que según los casos se establece; y otros configurados como conceptos jurídicos indeterminados, bien de carácter positivo, como la justificación de buena conducta cívica y el suficiente grado de integración en la sociedad española, o bien de carácter negativo, como los motivos de orden público o interés nacional que pueden justificar su denegación".

38. En virtud de los artículos 21 y 22.CC, el peticionario reúne los requisitos exigidos para obtener la nacionalidad, salvo la condición relacionada con el "suficiente grado de integración en la sociedad española"; puesto que está ligado por un vínculo matrimonial poligámico y esto no demuestra una integración efectiva en la sociedad española. El solicitante, como mencionamos, presentó entre los documentos de la solicitud de la nacionalidad un certificado de matrimonio en el que se consigna que contrajo matrimonio en la fecha de 13/02/1993, declarando las dos esposas "poligamia". La Audiencia Nacional confirma que la resolución del Director General de los Registros y del Notariado "contiene una clara y suficiente motivación"67. Esto es, el recurrente no ha acreditado suficiente grado de integración en la sociedad española, en virtud de lo previsto en el artículo 22.4.CC ${ }^{68}$. En este sentido, Castellanos Ruiz indica que «el sujeto que ejerce la poligamia de forma efectiva no podrá adquirir la nacionalidad española por residencia, porque éste no demuestra un "suficiente grado de integración en la sociedad española" ${ }^{69}$.

39. Según la Audiencia Nacional el requisito de suficiente grado de integración social «exige la aceptación y seguimiento de sus principios sociales básicos, especialmente aquellos recogidos en disposiciones legales que disciplinan los presupuestos esenciales de la convivencia entre ciudadanos ${ }^{70}$. En este punto, el recurrente no respeta el principio de "unidad del vínculo matrimonial" previsto en el Derecho español (art.46.2.CC), pues, el matrimonio monogámico es la única forma reconocida legalmente. Por lo tanto, si la administración pública detectase que el interesado está ligado por un vínculo matrimonial poligámico, aunque el solicitante de la nacionalidad cumpla con el resto de los requisitos administrativos y legales, su petición será denegada.

40. La Audiencia Nacional confirma que la poligamia es una institución contraria al orden público español, tal como confirma diversas sentencias del Tribunal Supremo que declaran que «la poligamia no es simplemente algo contrario a la legislación española, sino algo que repugna al orden público español, que constituye siempre un límite infranqueable a la eficacia del derecho extranjero (artículo 12.3.CC) $»^{71}$. Por eso, es ajustado a derecho que «la Administración española considere que alguien cuyo

\footnotetext{
${ }^{67}$ Apartado cuarto de los Fundamentos de Derecho del fallo de la SAN de Madrid de 4 de febrero de 2019.

68 Apartado cuarto de los Fundamentos de Derecho del fallo de la SAN de Madrid de 4 de febrero de 2019.

69 J. Ma . Castellanos Ruíz., "Denegación de la nacionalidad española por poligamia", Cuadernos de Derecho Transnacional, Vol.10, $\mathrm{n}^{\circ} 1,2018$, p.119.

${ }^{70}$ Apartado primero de los Fundamentos de Derecho del fallo de la SAN de Madrid de 4 de febrero de 2019.

71 En el apartado primero de los Fundamentos de Derecho de la STS (Sala de lo Contencioso-Administrativo) núm. 1982/2017, de 14 de diciembre (JUR $\backslash 2017 \backslash 313735$ ); en el apartado primero de los Fundamentos de Derecho de la STS (Sala de
} 
estado civil es atentatorio contra el orden público español no acredita un suficiente grado de integración en la sociedad española» ${ }^{72}$.

41. Por último, la Audiencia Nacional subraya que existen anteriores sentencias (Ss de 12 de junio de 2001, Rec.1105/2000 y 11 de junio de 2002, Rec.574/2001) que confirman «la imposibilidad de conceder la nacionalidad española en los supuestos de poligamia por falta del requisito de integración con los valores sociales, culturales y con nuestro propio ordenamiento jurídico» ${ }^{73}$. En este sentido, la SAN de 16/03/2018 (Sala de la contencioso-Administrativo, Sección 3a) declara que: "...no sólo porque es sumamente dudoso que la poligamia no suponga un rasgo de diferenciación notable en una sociedad que, aunque abierta y tolerante con usos y costumbres diferentes, no reconoce sino la unión matrimonial monógama, y además porque la ley española así lo dispone, de modo que resultaría contradictorio el reconocimiento de que se disfruta de una situación familiar diferente en virtud de leyes o costumbres distintos a los españoles en un aspecto tan importante de la organización social, y que se está en disposición de someterse a la obediencia de la Constitución y de las leyes españolas que impiden contraer matrimonio a quien ya se encuentra unido por vínculo conyugal"74. En suma, el recurrente en el presente caso está ligado por un vínculo matrimonial poligámico y esto no demuestra una integración efectiva en la sociedad española. En consecuencia, la carencia de este requisito exigido por el art.22.4.CC imposibilita obtener la nacionalidad.

\section{b) La nacionalidad tiene carácter político y es algo más que la autorización de residencia y trabajo}

42. La adquisición de la nacionalidad no se puede comparar en ningún caso con los efectos sociales y económicos derivados del matrimonio poligámico, esto es, los derechos concedidos por los tribunales españoles, como ocurre en la pensión de la viudedad y el derecho de alimentos. La adquisición de la nacionalidad tiene el carácter político de la soberanía del Estado. Por eso, los solicitantes de la nacionalidad deberían tener un mínimo conocimiento de las instituciones y organización política española. En este sentido, la Audiencia Nacional señala que en "el acta de audiencia ante el Encargado del Registro Civil en el que se consignen las concretar preguntas y cuestiones formuladas, no podemos valorar el grado de conocimiento de las instituciones y organización política española". No obstante, la Audiencia Nacional señala que «en el presente caso tal omisión no resulta relevante, pues, efectivamente, la denegación se fundamenta esencialmente en que el interesado aporta certificado de matrimonio, celebrado en Senegal, en el que consta que optó por el régimen de poligamia».

43. Tampoco se puede comparar la adquisición de la nacionalidad con la autorización de residencia y trabajo. Según el apartado tercero de la sentencia: «la nacionalidad constituye la máxima expresión jurídica de la integración de una persona en una comunidad estatal, y es algo más que la autorización de residencia y trabajo. Por ello, el nivel de exigencia de la adaptación a nuestra sociedad es superior para los solicitantes de la nacionalidad que el exigible a los extranjeros residentes, puesto

lo Contencioso-Administrativo) de 19 de diciembre de 2011 (RJ 2012 22876); en el apartado cuarto de los Fundamentos de la Derecho de la STS (Sala de lo Contencioso-Administrativo) de 26 de febrero de 2010 (RJ 2010 1571 ).

${ }^{72}$ Audiencia Nacional, Sala de lo Contencioso- administrativo, Sección 3a , Sentencia de 20 Octubre 2014, Rec. 826/2013; Audiencia Nacional, Sala de lo Contencioso-administrativo, Sección 3a , Sentencia de 16 Diciembre 2014, Rec. 1103/2013; Audiencia Nacional, Sala de lo Contencioso-administrativo, Sección 3a, Sentencia de 8 Mayo 2013, Rec. 136/2011.

${ }^{73}$ Apartado quinto de los Fundamentos de Derecho del fallo de la SAN de Madrid de 4 de febrero de 2019.

${ }^{74}$ Apartado quinto de los Fundamentos de Derecho del fallo de la SAN de Madrid de 4 de febrero de 2019. También el apartado tercero de los Fundamentos de Derecho de la SAN (Sala de lo Contencioso-Administrativo) de 11 de junio de 2002 (JUR \2003 \58420): esta es sentencia de la Audiencia Nacional recurrida, a raíz de la cual se dictó la STS (Sala de lo Contencioso-Administrativo) de 19 de junio de 2008 (RJ $2008 \backslash 6478$ ); apartado primero de los Fundamentos de Derecho de la STS (Sala de lo Contencioso-Administrativo) núm. 1982/2017, de 14 de diciembre (JUR\2017\313735) (ECLI:ES:TS:2017:4539): también haciendo referencia a la sentencia de la Audiencia Nacional recurrida, apartado cuarto de los Fundamentos de Derecho de

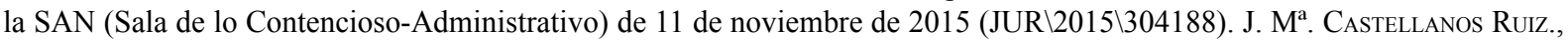
Denegación de la nacionalidad española por poligamia: Análisis jurisprudencial, op.cit, p.115. 
que pretenden ser ciudadanos españoles $\rangle^{75}$. La Audiencia Nacional explica que no es lo mismo residir en España que adquirir la nacionalidad española, que comporta toda una serie de derechos, incluidos el de sufragio activo y pasivo y el de acceder a los cargos y funciones públicas. La Audiencia Nacional destaca que «la adquisición de la nacionalidad convierte al peticionario en ciudadano español, lo cual supone que adquiere el derecho a participar en los asuntos públicos....y a acceder en condiciones de igualdad a las funciones y cargos públicos, como señala el artículo 23 de la Constitución». La Audiencia Nacional añade que «dicha participación en los asuntos públicos, como ciudadano español, abarca también la participación en el gobierno de las Entidades en que el Estado se organiza territorialmente, de acuerdo con el art.137 de la Constitución, más allá del derecho de sufragio como extranjeros residentes en los distintos municipios en las elecciones locales atendiendo a criterios de reciprocidad». El aspecto político de la adquisición de la nacionalidad, según la Audiencia Nacional, destaca también en que "la nacionalidad es la condición necesaria para acceder a la protección diplomática de los derechos de los nacionales de un país cuando se encuentran en el extranjero".

44. Por último, el ciudadano que obtiene la nacionalidad se convierte de un Estado miembro a ser Ciudadano de la Unión Europea «con los derechos reconocidos en las disposiciones del Derecho de la Unión relativas a la ciudadanía de la Unión, artículos 9 a 12 del Tratado de la Unión Europea (TUE), artículos 18 a 25 del Tratado de Funcionamiento de la Unión Europea (TFUE), y capítulo V de la Carta de Derechos Fundamentales de la Unión Europea». En resumen, el solicitante polígamo no podrá obtener la nacionalidad española, dado que la nacionalidad constituye la máxima expresión jurídica de la integración de una persona en una comunidad estatal, y el polígamo no satisface el nivel de integración exigido para los solicitantes de la nacionalidad.

\section{c) Los informes del Fiscal y la Juez, Encargada del Registro Civil, no tienen efecto vinculante}

45. El Fiscal y la Juez, Encargada del Registro Civil, como mencionamos, emitieron dos informes favorables a la concesión de la nacionalidad española al interesado. Conforme a los informes, el interesado ha demostrado suficiente asimilación del idioma y adaptación a la cultura española, tiene un buen nivel en lengua castellana y actividades laborales y aportó certificación de buena conducta cívica.

46. No obstante, la Audiencia Nacional ha destacado que tener un buen nivel de la lengua castellana junto con el desarrollo de actividades laborales por el interesado «son factores a tener en cuenta, pero no son los únicos ni son determinantes para acreditar un suficiente grado de integración social» ${ }^{76}$. Según la Audiencia Nacional el requisito de suficiente grado de integración social «exige la aceptación y seguimiento de sus principios sociales básicos, especialmente aquellos recogidos en disposiciones legales que disciplinan los presupuestos esenciales de la convivencia entre ciudadanos» $\rangle^{77}$. En este caso, el recurrente practica la poligamia y por tanto no respeta las normas del Derecho español, en concreto, el principio de "unidad del vínculo matrimonial" previsto en el (art.46.2.CC).

47. La Audiencia Nacional sostiene que los informes emitidos por el Encargado del Registro Civil y el Ministerio Fiscal "no tienen efecto vinculante"78. Esto quiere decir que los informes emitidos se tratan de una mera información o una simple propuesta para el Ministerio de Justicia, y no tienen carácter obligatorio ante los juzgados. «Tales informes deben contemplarse en el marco del procedimiento

\footnotetext{
${ }^{75}$ En el mismo sentido viene la STS (Sala de lo Contencioso-Administrativo) de 26 de julio de 2004, en el apartado cuarto de los Fundamentos de Derecho de (RJ 2004\5546); y la STS (Sala de lo Contencioso-Administrativo) de 19 de junio de 2008, apartado tercero de los Fundamentos de Derecho de (RJ $\backslash 2008 \backslash 6478)$.

${ }^{76}$ Apartado quinto de los Fundamentos de Derecho del fallo de la SAN de Madrid de 4 de febrero de 2019.

${ }_{77}$ Apartado primero de los Fundamentos de Derecho del fallo de la SAN de Madrid de 4 de febrero de 2019.

${ }^{78}$ Conforme resulta con carácter general de los artículos 82 y 83 de la Ley 30/1992 de 26 de noviembre de Régimen Jurídico de las Administraciones Públicas y del Procedimiento Administrativo Común (hoy 79 y 80 de la Ley 39/2016 de Procedimiento Administrativo Común de las Administraciones Públicas)".
} 
instructor, con los efectos que les son propios, sin desconocer que la decisión del procedimiento corresponde a la Dirección General de Registros y Notariado (artículos 221 y 22 RLRC) $\gg^{79}$.

\section{d) Los requisitos de la concesión de la nacionalidad por residencia han de cumplirse y acreditase en el momento de la presentación de la solicitud}

48. El segundo motivo formal de desestimar el recurso por parte de la Audiencia Nacional se vincula con el nuevo certificado matrimonial presentado por el recurrente, en lo cual el interesado renuncia a la poligamia. En la demanda ante la Audiencia Nacional el recurrente alega que tras la denegación de la solicitud de nacionalidad y la interposición del recurso de reposición contra la resolución denegatoria, presentó escrito ampliatorio con el que aportó certificado de matrimonio actualizado renunciando a la poligamia. No obstante, la DGRN no tuvo en cuenta el nuevo documento presentado confirmando la resolución denegatoria de la nacionalidad.

49. La Audiencia Nacional después de revisar el recurso de reposición ha descubierto que el recurrente reside en España desde 1985, contrajo matrimonio en su país en febrero de 1993, optando por la poligamia, solicitó la nacionalidad en diciembre de 2010 y no es hasta 2015 cuando manifiesta renunciar a la poligamia y acogerse a la monogamia. Se puede afirmar que el recurrente era polígamo en el momento de presentar la solicitud de nacionalidad española en 2010, y no ha manifestado su voluntad de renunciar a la poligamia hasta 2015, cuando la Dirección le denegó la nacionalidad por motivo de la poligamia. Con lo que plantea dudas sobre su intención de renunciar al régimen de la poligamia. En resumen, el certificado de matrimonio que declara las dos esposas muestra, desde la perspectiva de las autoridades españolas, que el solicitante aún no estaba lo suficientemente integrado en la cultura española. En otras palabras, el interesado debía renunciar a la poligamia antes de la presentación de su solicitud de la nacionalidad en el año 2010 y no después de denegar su solicitud por la DGRN en 03/12/2015.

50. Por otro lado, el nuevo certificado de matrimonio aportado por el recurrente en el recurso de reposición no ha sido incorporado al expediente administrativo, por lo que no pudo ser valorado por la Administración. Por eso, la DGRN denegó el recurso en la fecha 15 de junio de 2017, confirmando su resolución denegatoria de la nacionalidad, puesto que los requisitos para ser acreedor a la concesión de la nacionalidad española por residencia han de cumplirse y acreditarse en el momento de la solicitud, cuestión relevante y concluyente que no se cumple en el presente caso.

51. El Tribunal Supremo en la sentencia de 4 de julio de 2011 subraya que la renuncia de la poligamia debería ser durante el período de residencia legal en España, para cumplir el requisito de integración social. Según el Tribunal Supremo: «la opción por la poligamia al contraer matrimonio en Senegal durante el período de residencia legal en España y el mantenimiento de esta situación aunque la opción no se haya hecho efectiva, revela una falta de integración en la sociedad española en el sentido exigido por el art.22.4.CC y de la jurisprudencia» ${ }^{80}$.

52. En un caso contrario, en la sentencia de 16 de diciembre de $2014^{81}$ la Audiencia Nacional ha estimado el recurso presentado por un ciudadano de Gambia y se le ha concedido la nacionalidad española, en contra de la opinión de la DGRN. La DGRN denegó la nacionalidad al sujeto por no haber acreditado de nuevo su renuncia a la opción de poligamia. Efectivamente el interesado estaba casado con dos mujeres, sin embargo, en el momento de la solicitud de nacionalidad española se había divorciado de una de ellas, de modo que desde el 12 de diciembre de 2009 el sujeto era monógamo, fecha anterior de la solicitud de la nacionalidad, el 19 de noviembre de 2010. Por eso, la Sala ha declarado «que se debe tener

\footnotetext{
${ }^{79}$ Apartado sexto de los Fundamentos de Derecho del fallo de la SAN de Madrid de 4 de febrero de 2019.

${ }^{80} \mathrm{M}^{\mathrm{a}}$. J. SÁnchez CANo., Poligamia y Derecho Internacional Privado ante el Tribunal Supremo, op.cit, pp.529-544.

${ }^{81}$ SAN (Sala de lo Contencioso-Administrativo) de 16 de diciembre de 2014 (JUR 2015 118559) (ECLI:ES:AN:2014: 5127).
} 
en cuenta que el proceso de integración de los extranjeros en el país del que pretender ser nacionales, debe ser paulatina» ${ }^{82}$. Según la sentencia de la Audiencia Nacional «los usos de la sociedad en que pretenden integrarse deben asumirse, pero no puede exigirse a quien procede de un país, Gambia, donde la polígama es legal y es socialmente aceptada, que deba no haber incurrido en tal costumbre. Lo cierto y averiguado es que el demandante solicitó la nacionalidad española el 19 de noviembre de 2010 y que en esa fecha era monógamo ${ }^{83}$. El tribunal considera que aunque la haya ejercido la poligamia, la ha dejado de ejercer, quedando probado de forma clara que cuando instó la solicitud de la nacionalidad era monógamo ${ }^{84}$.

53. Se puede concluir que en el recurso presentado ante la Audiencia Nacional en este estudio expuesto, el interesado debía renunciar a la poligamia antes de la presentación de su solicitud de la nacionalidad en el año 2010 y no después de denegar su solicitud por la DGRN en 03/12/2015. El recurrente era polígamo en el momento de presentar la solicitud de nacionalidad española en 2010, y no ha manifestado su voluntad de renunciar a la poligamia hasta 2015.

54. Por todos los motivos mencionados la Audiencia Nacional desestimó el recurso contencioso- administrativo interpuesto contra la Resolución del Ministro de Justicia, que denegó la concesión de la nacionalidad española por falta de integración en la sociedad española, por haber sido ajustada a Derecho, con condena en costas a la parte recurrente, hasta el límite de $1000 €$, por todos los conceptos, confirmando así la resolución recurrida por haber sido ajustada a Derecho. La sentencia es susceptible de recurso de casación que deberá prepararse ante esta Sala en el plazo de 30 días contados desde el siguiente al de su notificación.

Concluimos la exposición de este estudio, destacando las consideraciones finales.

\section{Consideraciones finales}

55. La sentencia de la Audiencia Nacional de Madrid de 4 de febrero de 2019 coincide con otras sentencias anteriores dictadas por el Tribunal Supremo. Los juzgados deniegan la concesión de la nacionalidad por residencia a los sujetos que están ligados por un matrimonio poligámico, (y aún sin estarlo, cuando no conste la renuncia a la opción por la poligamia). El motivo de la denegación es el mismo, esto es, "insuficiente grado de integración en la sociedad española". El polígamo no satisface el nivel mínimo exigido de integración para los solicitantes de la nacionalidad, y por lo tanto su solicitud será denegada. El concepto de "suficiente grado de integración en la sociedad española" no deriva sólo del idioma y el desarrollo de actividades laborales por el solicitante, sino exige del solicitante una convivencia con los principios y valores sociales y culturales, y así, respetar las normas y leyes del Estado que solicita su nacionalidad, entre sí, el principio de la unidad del vínculo matrimonial.

56. La nacionalidad constituye la máxima expresión jurídica de la integración de una persona en una comunidad estatal, tal como deciden los tribunales españoles en diversas sentencias. Por eso, si el ciudadano extranjero no renuncia a la poligamia antes de presentar su solicitud, esto puede entenderse como un elemento indicador de la ausencia de voluntad de integración en la sociedad. En este ámbito, la adquisición de la nacionalidad no se puede comparar con la concesión de los derechos sociales y económicos confirmados por los tribunales en diversas sentencias, como la pensión de la viudedad. La adquisición de la nacionalidad tiene el carácter político de la soberanía del Estado, la cual implica una serie de derechos y responsabilidades relevantes, como por ejemplo acceder a los cargos públicos y la participación en el gobierno de las Entidades en que el Estado se organiza territorialmente.

\footnotetext{
${ }^{82}$ J. Ma . Castellanos Ruzz., Denegación de la nacionalidad española por poligamia: Análisis jurisprudencial, op.cit, p.104.

${ }^{83}$ Apartado tercero de los Fundamentos de Derecho de la SAN, (Sala de lo Contencioso-Administrativo) de 16 de diciembre de 2014 (JUR\2015\18559) (ECLI:ES:AN: 2014:5127).

${ }^{84}$ J. Ma . CAstellanos Ruzz., Denegación de la nacionalidad española por poligamia: Análisis jurisprudencial, op.cit, p.105.
} 
57. Un análisis de las sentencias de los tribunales destaca que adoptan respecto a los efectos generados del matrimonio poligámico una doctrina selectiva y estricta. Es decir, en los juicios vinculados con efectos producidos del matrimonio poligámico y solicitados por la esposa, como ocurre en caso de la pensión de la viudedad, la tendencia jurisdiccional es tolerante y respalda a los derechos de la mujer y los hijos del polígamo. Mientras que, en caso del esposo polígamo, la perspectiva administrativa y jurisdiccional es estricta y sancionadora. Dado que, el marido polígamo viola las normas del orden público y por ende comete un delito castigado por el Código penal. Por lo tanto, no puede beneficiar en cualquier caso de un sistema contraria al orden público internacional español, sino al contrario, debería asumir todas las consecuencias negativas de su acto ilícito, esto es, la denegación de su solicitud de la nacionalidad.

58. Ciertamente la poligamia constituye un reto y una carga ante los ordenamientos occidentales, con el aumento de las reclamaciones judiciales de derechos vinculados con el matrimonio poligámico. Ahora bien, la tendencia hacia una interpretación más flexible y razonable del orden público representa una necesidad que los ordenamientos europeos no pueden ignorar, siempre que el caso se vincula con la viuda, la esposa y los hijos del polígamo, sujetos de una institución, que aún siendo efectivamente contraria al orden público, no siempre genera efectos que contravengan los principios fundamentales del foro. En esta materia las autoridades judiciales podrían acudir a los Convenios de Derecho Humanos y los Tratados internacionales, ratificados por todos los Estados europeos, para garantizar la protección jurídica y económica de la mujer del polígamo (y por supuesto a sus hijos), ya sea en condición de esposa, viuda o divorciada.

59. En nuestro modo de ver, la posición de los tribunales europeos, incluidos los españoles, respecto a los efectos derivados del casamiento poligámico aun no está clara y determinante, no hay unanimidad judicial en las cuestiones relacionadas con el matrimonio poligámico. Habrá que esperar las futuras decisiones de los tribunales, esto es, para conocer cuáles su postura definitiva en esta materia tan polémica. 